\title{
ANALISIS KADAR VITAMIN C PADA DAGING BUAH DURIAN MAMUJU (DURIO ZIBETHINUS MURR) SECARA KUALITATIF DAN KUANTITATIF
}

\author{
Aminah Hamzah
}

Fakultas Farmasi Universitas Muslim Indonesia

\begin{abstract}
Have been conducted by a obstetrical research of vitamin $C$ at durio meat of Mamuju by qualitative and quantitatif.. The research aim to determine of vitamin $C$ from durio meat of Mamuju by qualitative and quantitatif. Firstly fruit of durio are separated by their seed then it weighed that it enchanced by oxxilate acid $0.4 \%$ and that it blended and filtered. Fitrat obtained to qualitative analyze by using the react $\mathrm{FeCl}_{3}$, Fehling and rate determined quantitatively vitamin $\mathrm{C}$ using the spectrophotometry UV-Visible at wave legth $516 \mathrm{~nm}$ obrtained rate of mean vitamin $C$ that is durio meat of Mamuju $65.42 \mathrm{mg} / 100 \mathrm{~g}$.
\end{abstract}

Key Words : Durio Zibethinus Murr, Analysis, Vitamin C, qualitative and quantitatif.

\section{PENDAHULUAN}

Vitamin merupakan senyawa organik yang penting bagi kehidupan, aktif secara fisiologik yang didalam tubuh manusia di bentuk sangat sedikit dengan bantuan faktor luar tertentu. Kandungan vitamin dalam makanan bergantung pada cara produksi, penyimpanan dan penyiapan.

Vitamin C atau Asam Askorbat adalah salah satu vitamin yang larut dalam air. Kebutuhan tubuh akan vitamin C kurang lebih $60 \mathrm{mg}$ setiap hari. Fungsi vitamin $\mathrm{C}$ sangat kompleks dan yang terpenting adalah pembentukan suatu bentuk kimia kolagen, yakni protein bahan penunjang utama dalam tulang rawan dan jaringan ikat. Bila sintesa kolagen terganggu, maka mudah terjadi kerusakan pada dinding pembuluh darah yang berakibat perdarahan (Winarno, 2004).

Vitamin C tidak terdistribusi secara luas dalam bahan makanan seperti kebanyakan vitamin yang lain. Vitamin C hampir ditemukan sepenuhnya dalam makanan nabati, yaitu sayuran dan buah-buahan segar. Jumlah vitamin $C$ dalam sayuran dan buah-buahan sangat bervariasi 
Analisis Kadar Vitamin C Pada Daging Buah Durian Mamuju Secara Kualitatif Dan Kuantitatif

bahkan dalam varietas yang sama sekalipun (Rahimsyah, 1998).

Kekurangan vitamin C menyebabkan penyakit scorbut atau perdarahan di sekitar gusi, untuk menghindari kekurangan vitamin ini, perlu mengkonsumsi vitamin $\mathrm{C}$. Sebagai sumber vitamin $\mathrm{C}$ buah durian sangai baik untuk mengobati sariawan sebagai anti infeksi, dan membantu penyerapan zat besi dan kalsium, membantu perkembangan tulang dan gigi, dan menghambat pertumbuhan nitrosamine.

Sumber vitamin C sebagian besar berasal dari sayuran dan buahbuahan, terutama buah-buahan segar. Karena itu vitamin C sering disebut Fresh Food vitamin (Winarno, 1984).

Salah satu tanaman yang dimanfaatkan untuk keperluan makanan buah-buahan adalah buah durian (Durio zibethinus Murr). Dimana salah satu daerah penghasil durian terbesar adalah Mamuju dan Palopo untuk wilayah Sulawesi Barat dan Sulawesi Selatan.

\section{METODE PENELITIAN}

Adapun Jenis penelitian yang digunakan dalam penelitian ini adalah eksperimental laboratories.

Alat dan Bahan, Alat dan bahan yang akan digunakan disiapkan sesuai dengan kebutuhan penelitian dari penelitian tersebut.

\section{A. Prosedur Penelitian}

\section{Pengambilan sampel}

Sampel durian (Durio ziberthinus Murr), yang segar yang akan dianalisis dalam penelitian ini berupa durian dari Mamuju

\section{Penyiapan larutan sampel}

Sampel Durian (Durio ziberthinus Murr), yang mana diambil daging buahnya dan ditimbang 10,0 g kemudian ditambahkan $100 \mathrm{ml}$ asam oksalat $0,4 \%$, di blender dan di saring. Diambil fitratnya dan dimasukkan ke dalam labu ukur $250 \mathrm{ml}$ dan dicukupkan hingga batas tanda dengan larutan asam oksalat $0,4 \%$.

\section{Pengujian sampel}

a. Analisis kualitatif dari vitamin C

1) Larutan Fehling $A$ dan Fehling B dicampurkan lalu ditambahkan larutan sampel, jika mengandung vitamin $\mathrm{C}$ maka terbentuk endapan merah bata.

2) Larutan sampel ditambahkan larutan $\mathrm{FeCl}_{3}$, jika mengandung 
Analisis Kadar Vitamin C Pada Daging Buah Durian Mamuju Secara Kualitatif Dan Kuantitatif

vitamin C maka
terbentuk larutan kuning
cepat hilang.

b. Analisis kuantitatif vitamin

C secara spektrofotometri UV-Vis

1) Pembuatan Stabilizer

Ditimbang 0,24 g

Na.EDTA dimasukkan ke dalam labu takar $1000 \mathrm{ml}$ dan dicukupkan dengan larutan Buffer asetat $\mathrm{pH}$ 4,1 hingga batas tanda.

2) Pembuatan larutan baku vitamin $\mathrm{C}$

Ditimbang dengan teliti $100,0 \mathrm{mg}$ asam askorbat murni, dimasukkan ke dalam labu takar $250 \mathrm{ml}$, dilarutkan dengan larutan Buffer asetat $\mathrm{pH} \quad 4,1$ hingga $100 \mathrm{ml}$ (250 bpj)

3) Penentuan panjang gelombang maksimum

Di ambil $1 \mathrm{ml}$ larutan asam askorbat, dimasukkan ke dalam labu takar $25 \mathrm{ml}$ dan dilarutkan dengan stabilizer hingga batas tanda (8 bpj).

4) Pembuatan kurva baku

Di pipet $25 \mathrm{ml}$ larutan baku asam askorbat, dimasukkan ke dalam labu $100 \mathrm{ml}$, dilarutkan dengan larutan stabilizer hingga batas tanda (250 bpj). Dari larutan tersebut dipipet $0,1 \mathrm{ml}$ larutan kemudian dimasukkan ke dalam labu ukur $25 \mathrm{ml}$ dan cukupkan dengan larutan stabilizer (2 bpj) lanjutkan dengan pengenceran $4,6,8,10$ bpj dalam labu ukur 25 $\mathrm{ml}$.

Dilakukan

pengukuran pada spektrofotometri UV-Vis dengan panjang gelombang $516 \mathrm{~nm}$.

5) Pengukuran kadar volume vitamin C dalam sampel

Dipipet dengan teliti $1 \mathrm{ml}$ larutan sampel ke dalam labu ukur $25 \mathrm{ml}$ dan dicukupkan dengan larutan stabilizer hingga batas tanda, dikocok setelah itu diukur serapannya pada panjang gelombang 516 $\mathrm{nm}$. 
Analisis Kadar Vitamin C Pada Daging Buah Durian Mamuju Secara Kualitatif Dan Kuantitatif

\section{6) Perhitungan kadar vitamin $\mathbf{C}$}

Perhitungan kadar

vitamin C dilakukan

dengan cara

mengekstrapolasikan

data serapan vitamin C

pada persamaan regresi

linier dari kurva baku

vitamin $\mathrm{C}$.

7) Analisis data

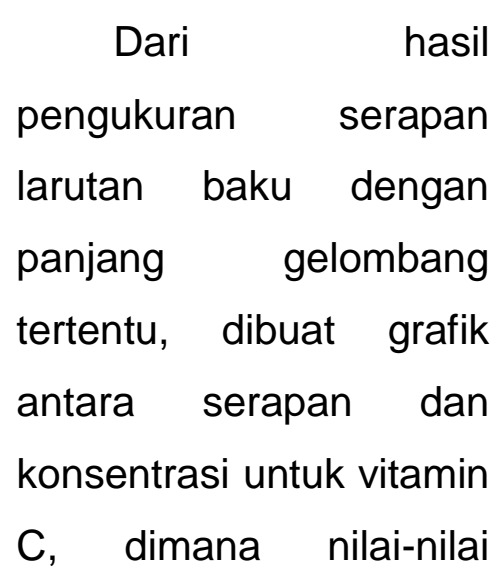

serapan pada sumbu $\mathrm{Y}$ dan konsentrasi pada sumbu $\mathrm{X}$, kemudian ditarik garis diantara titik untuk memperoleh persamaan garis lurus :

$\mathbf{Y}=\mathbf{a}+\mathbf{b X}$

\section{Dimana :}

$a=$ intersep

b = slope/kemiringan

Dari persamaan regresi linear selanjutnya dihitung konsentrasi sampel dengan cara hasil-hasil serapann diplotkan terhadap persamaan regresi tersebut.

\section{HASIL PENELITIAN}

Tabel 1. Hasil Analisis Kualitatif Vitamin C Pada Durian (Durio ziberthinus Murr)

\begin{tabular}{cccccc}
\hline \multirow{2}{*}{ No } & Pereaksi & \multicolumn{2}{c}{ Hasil Pereaksi } & Pustaka & Keterangan \\
\cline { 3 - 5 } & A & B & & Endapan \\
1. & P1 & $\begin{array}{c}\text { Endapan merah } \\
\text { bata }\end{array}$ & $\begin{array}{c}\text { Endapan } \\
\text { merah bata }\end{array}$ & Positif $(+)$ \\
\hline 2. & P2 & $\begin{array}{c}\text { Warna kuning } \\
\text { cepat hilang }\end{array}$ & $\begin{array}{c}\text { Warna kuning } \\
\text { cepat hilang }\end{array}$ & $\begin{array}{c}\text { Warna kuning } \\
\text { cepat hilang }\end{array}$ & Positif $(+)$ \\
\hline
\end{tabular}

\section{Keterangan :}

Pereaksi (P1) : Fehling

Pereaksi (P2) : $\mathrm{FeCl}_{3}$
A
: Asam Askorbat murni
B
: Durian Mamuju (Durio ziberthinus Murr) 
Analisis Kadar Vitamin C Pada Daging Buah Durian Mamuju Secara Kualitatif Dan Kuantitatif

Tabel 2. Analisis Pengukuran Serapan Larutan Baku Asam Askorbat Dengan Spektrofotometri UV-Vis Pada Panjang Gelombang 516 nm.

\begin{tabular}{ccc}
\hline No. & Konsentrasi (ppm) & Absorban \\
\hline 1 & 2 & 0.189 \\
2 & 4 & 0.271 \\
3 & 6 & 0.414 \\
4 & 8 & 0.543 \\
5 & 10 & 0.731 \\
\hline
\end{tabular}

Tabel 3.Hasil Analisis Kuantitatif Vitamin C Pada Durian (Durio ziberthinus Murr) Secara Spektrofotometri UV-Vis.

\begin{tabular}{cccccc}
\hline $\begin{array}{c}\text { Asal } \\
\text { Durian }\end{array}$ & $\begin{array}{c}\text { Berat } \\
\text { Sampel }(\mathbf{g})\end{array}$ & $\begin{array}{c}\text { Absorban } \\
(\mathbf{A})\end{array}$ & $\begin{array}{c}\text { Kadar } \\
(\mathbf{m g} / \mathbf{g})\end{array}$ & $\begin{array}{c}\text { Kadar } \\
(\mathbf{m g} / \mathbf{1 0 0 g})\end{array}$ & $\begin{array}{c}\text { Kadar rata-rata } \\
(\mathbf{m g} / \mathbf{1 0 0 g})\end{array}$ \\
\hline \multirow{3}{*}{ Mamuju } & \multirow{2}{*}{10.012} & 0.733 & 0.6543 & 65.43 & \\
& & 0.734 & 0.6542 & 65.42 & 65.42 \\
\hline
\end{tabular}

\section{PEMBAHASAN}

Penelitian ini bertujuan untuk menentukan dan membandingkan kadar vitamin C yang terkandung dalam daging buah durian (Durio ziberthinus Murr) dari daerah Mamuju yang dianalisis secara kualitatif dan kuantitatif.

Sebelum dilakukan penelitian terlebih dahulu dilakukan pengambilan sampel, dimana harus diperhatikan kualitasnya. Buah durian yang berkualitas baik biasanya tidak dipetik tetapi buah yang jatuh dengan sendiri dari pohonnya karena buah yang dipetik biasanya belum terlalu matang.

Pada penelitian ini dilakukkan uji kualitatif dan uji kuantitatif, yang terlebih dahulu penyiapan larutan sampel dimana daging buah durian (Durio ziberthinus Murr) dari Mamuju dipisahkan dari bijinnya dan ditimbang. Selanjutnya daging buah durian tersebut diblender dan dilarutkan dengan menggunkanan asam oksalat 0,4\% sebanyak $100 \mathrm{ml}$. Asam oksalat berguna sebagai pelarut untuk mencegah teroksidasinya vitamin $\mathrm{C}$. Vitamin C dapat bereaksi dengan pereduksi yang kuat seperti asam oksalat sehingga vitamin C yang teroksidasi asam dehidroaskorbat dapat menjadi asam askorbat kembali.

Analisis kualitatif dilakukkan dengan menggunakan beberapa macam pereaksi yang spesifik dengan tujuan untuk mengetahui ada atau tidaknya vitamin $\mathrm{C}$ pada daging buah 
Analisis Kadar Vitamin C Pada Daging Buah Durian Mamuju Secara Kualitatif Dan Kuantitatif

durian (Durio ziberthinus). Adapun pereaksi spesifik yang digunakan adalah $\mathrm{FeCl}_{3}$ dan fehling. Hasil yang diperoleh semuanya positif sesuai dengan pustaka yaitu adanya endapan merah bata dengan penambahan fehling dan berwarna kuning dengan adanya penambahan pereaksi $\mathrm{FeCl}_{3}$.

Pada analisis kuantitatif sampel diblender dan dilarutkan dengan meggunakan asam oksalat $0,4 \%$. Asam oksalat ini berguna untuk mencegah pengaruh ion tembaga sehingga dapat bereaksi dengan stabiliizer (Na. EDTA + Buffer Asetat $\mathrm{PH}$ 4,1) yang akan terukur menjadi vitamin $C$, dalam hal ini yang akan teroksidasi setara dengan stabiliizer, yang tereduksi diperoleh dari hasil pengukuran stabiliizer awal dengan EDTA dan asetat yang bereaksi dengan asam oksalat menjadi tidak berwarna. Penetapan kadar secara spektrofotometri sinar tampak meggunakan pereaksi stabiliizer, reaksi ini didasarkan atas pengukuran jumlah larutan stabiliizer yang dihilangkan warnanya oleh vitamin $\mathrm{C}$. Intensitas warna dari stabiliizer dengan vitamin $\mathrm{C}$ tidak tergantung terhadap waktu karena distabilkan dengan adanya penambahan stabilizer ( $\mathrm{Na}$. EDTA + Buffer Asetat PH 4,1), sehingga absorbansi yang diperoleh dan secara langsung ditetapkan kadarnya.

Berdasarkan hasil penelitian maka diperoleh kadar rata-rata vitamin C pada daging buah durian Mamuju yaitu $65.42 \mathrm{mg} / 100 \mathrm{~g}$. Pada umumnya kebanyakan orang menganggap jika dibandingkan dengan buah jeruk kandungan vitamin C-nya sangat tinggi jikadilihat dari penampilannya namun ternyata daging buah durian jauh lebih banyak mengandung vitamin $\mathrm{C}$, yaitu sekitar hampir dua kali lipat dari jeruk hanya mengandung $49 \mathrm{mg} / 100 \mathrm{gram}$.

\section{KESIMPULAN}

Berdasarkan hasil pengamatan dan pengolahan data menunjukkan bahwa Kadar rata-rata vitamin C yang diperoleh pada daging buah durian (Durio ziberthinus Murr) dari Mamuju yaitu $65.42 \mathrm{mg} / 100 \mathrm{~g}$.

\section{DAFTAR PUSTAKA}

Apriadji, (2007), Makanan Sehat Untuk Hidup Sehat, Bahagia dan Awet Muda. Penetbit PT. Gramedia Pustaka Utama, Jakarta.

Gandjar, I.G., Rohman, A., (2007), Kimia Farmasi Analisis. Penerbit Pustaka Pelajar, UGM, Yogyakarta.

Ganiswara, S., (1995), Farmakologi dan Terapi. FKUI, Jakarta. 
Analisis Kadar Vitamin C Pada Daging Buah Durian Mamuju Secara Kualitatif Dan Kuantitatif

Husain, I., dkk., (2010), UV Spectrophotometric Analysic Profile of Ascorbic Acid in Medicinal Plants of Pakistan. World Applied Sciences Journal Volume 9 (7). Hal. 800-803.

John Deman, (1997, Kimia Makanan. Penerbit Kanisius, Yogyakarta.

Kartasapoetra, G., (2008), IImu Gizi.

Penerbit PT. Rineka Cipta, Jakarta.

Khopkar, K., (1990), Konsep Dasar Kimia Analitik, Penerbit UIPress, Jakarta.

Kosman, R., (2007), Bahan Ajar Kimia Fisika. Penerbit universitas Muslim Indonesia, Makassar.

Kumalaningsih, (2006), Antioksidan Alami. Penerbit Trubus Agrisarana, Jakarta.

Mutshler, (1991), Dinamika Obat. Penerbit Institut Teknologi Bandung, Bandung.

Soedarya, A.P., (2009), Agrobisnis Durian. Penerbit Grafika, Bandung.

Sudarmadji, Slamet, (2003), Analisis Bahan Makanan dan Pertanian. Penerbit Liberty Yogyakarta UGM, Yogyakarta.

Tjay, T.H., (2002), Obat-Obat Penting. PT. Elex Media Komputindo, Jakarta.

Winarno, F.G., (1984), Kimia Pangan dan Gizi. Penerbit Gramedia, Jakarta. 